Arq. Bras. Med. Vet. Zootec., v.72, n.3, p.915-920, 2020

\title{
Effect of nabumetone on humoral immune responses in mice
}

[Efeito da nabumetona nas respostas imunes humorais em camundongos]

Khalid Naveed ${ }^{1}$, Aqeel Javeed ${ }^{1 *}$, Muhammad Ashraf ${ }^{1}$, Amjad Riaz ${ }^{2}$, Aamir Ghafoor ${ }^{3}$, Adeel Sattar ${ }^{1}$

\begin{abstract}
${ }^{1}$ Department of Pharmacology and Toxicology, University of Veterinary and Animal Sciences, Lahore-Pakistan ${ }^{2}$ Department of Theriogenology, University of Veterinary and Animal Sciences, Lahore-Pakistan ${ }^{3}$ University Diagnostic Lab, University of Veterinary and Animal Sciences, Lahore- Pakistan
\end{abstract}

\begin{abstract}
Nabumetone is used to reduce the pain and inflammation in rheumatoid arthritis. In the current study, immunomodulatory effect of Nabumetone is investigated in mice. The control group was administered normal saline orally as placebo. Nabumetone was administered orally via gavage in two treatment groups at $14 \mathrm{mg} / \mathrm{kg}$.b.w. doses and $28 \mathrm{mg} / \mathrm{kgb}$.w., respectively. Haemagglutination (HA) assay, Jerne hemolytic plaque and mice lethality assays were applied. In HA assay, the titer was significantly decreased in Nabumetone treatment groups $(\mathrm{P}<0.001)$. In Jerne hemolytic plaque formation assay, there was a significant reduction $(\mathrm{P}<0.001)$ in number of plaques in Nabumetone treated groups when compared with control. In mice lethality assay, there was a significant difference in mortality ratio of mice in control and Nabumetone treated groups $(\mathrm{P}<0.001)$. Therefore, it is concluded that Nabumetone suppresses the humoral immune response in mice.
\end{abstract}

Keywords: nabumetone, humoral immunity, mice

\section{[RESUMO]}

A nabumetona é usada na redução da dor e inflamação da artrite reumática. No presente estudo, o efeito imunomodulador é investigado em camundongos. O grupo de controle recebeu solução salina via oral como placebo. Nabumetona foi administrada oralmente via gavagem em dois grupos de tratamentos com doses de $14 \mathrm{mg} / \mathrm{kg}$. b.w. e 28mg/kgb.w., respectivamente. Foram realizados ensaios de hemaglutinação (HA), placa hemolítica de Jerne e letalidade dos camundongos. No ensaio HA, o grau foi significativamente menor nos grupos de tratamento com nabumetoma $(P<0.001)$. No ensaio de formação de placa hemolítica de Jerne houve redução significativa $(P<0.001)$ no número de placas em grupos tratados com nabumetoma comparado ao controle. No ensaio de letalidade dos camundongos houve diferença significativa no grau de mortalidade de camundongos no grupo de controle e grupos tratados com nabumetoma ( $P<0.001)$. Portanto, conclui-se que a Nabumetoma suprime a resposta imune humoral em camundongos.

Palavras-chave: nabumetoma, imunidade humoral, camundongos

\section{INTRODUCTION}

Nabumetone is a non-acid pro-drug approved by the Food and Drug Administration authority in 1991. It is a non-steroidal anti-inflammatory drug used in conditions such as rheumatoid arthritis, osteoarthritis, and any other disease associated with pain. Nabumetone is a pro-drug.

Recebido em 13 de fevereiro de 2019

Aceito em 2 de agosto de 2019

*Autor para correspondência (corresponding author)

E-mail: aqeel.javeed@uvas.edu.pk
Therefore, it is essentially taken through oral route. Nabumetone is derived from 1-naphthyl acetic acid and inhibits the cyclooxygenase enzymes (Hassan et al., 2004). It belongs to the 2.6-substituted naphthyl alkaline class of nonsteroidal anti-inflammatory drugs, and 6methoxy 2-naphthyl acetic acid is its active metabolite which is mainly responsible for its pharmacological action as this active metabolite 
reaches the joint fluid (Klebanoff et al., 2005; Muneer et al., 2005). It has been found that Nabumetone has very few undesired health effects. Nabumetone is also used for the control of blood pressure in hypertensive patients on ACE inhibitors (Muneer et al., 2005). For every 24 hours, one-gram dose is enough to produce the desired effect, and its effect is roughly equivalent to other group members like naproxen, indomethacin, decolophenic, sulindac, aspirin and ibuprofen. However, Nabumetone exhibits little negative effects that is why it is tolerated (Gonzalo-Garijo et al., 2007).

Cyclo-oxygenases are not directly involved in different functions, but they result in the production of prostanoids (prostaglandins, prostacyclin and thromboxane), which are responsible for different immunomodulatory effects. Immunity, which defends the host from infections, may be acquired or innate. COX-2 expression is increased during inflammation and may play an important role in immune regulation. Cyclooxygenase-1 shows some physiological functions (Bernard et al., 2010).

The role of the humoral immune system is to produce antibodies in order to defend the body against variety of pathogens (Kerola et al., 2009). Humoral or antibody immune responses protect against bacterial attack. After stimulation of $\mathrm{B}$ cells, $\operatorname{IgA}$ and $\mathrm{IgG}$ are produced to destroy pathogens (Kruetzmann et al., 2003). B cells are produced from plasma cells (Fulzele et al., 2003). Plasma cells can release large amounts of a single type of antibody. Varieties of plasma cells have been tested to explore the mechanism of formation of B cells. The decrease of $\mathrm{B}$ and $\mathrm{T}$ lymphocytes occurs due to the lack of immune functions (Shapiro-Shelef and Calame, 2005).

Nabumetone is immunosuppressant (Koenig et al., 2016). This drug may inhibit cell mediated immunity and antibody titer and lower the defense power of the body. Due to its immunosuppressant property, this may be considered as a potential drug for organ transplantation and autoimmune diseases due to its antipyretic, anti-inflammatory and analgesic effects. Therefore, the humoral immunomodulatory effect of Nabumetone was studied in the present study. The purpose of the present work was to evaluate the immunomodulatory of Nabumetone in albino mice which might help to prevent the rejection of transplanted organs and autoimmune disorders.

\section{MATERIALS AND METHODS}

Albino mice were provided by the University of Veterinary and Animal Sciences in Lahore, Pakistan. In a standard environment, these experimental animals were kept in a separate house for research purposes. In the present research, mice at five to seven weeks of age were used. All hygienic standards were observed throughout experiment. The mice were provided with hygienic, clean water ad libitum and with pelleted feed. All international standards for the maintenance and care of laboratory animals were followed in all experiments.

Antigen: Sheep red blood cells were obtained from the department of microbiology of the UVAS, Lahore. A Pasteurella multocida culture was obtained from the diagnostic laboratory of the UVAS, Lahore.

Chemicals: Nabumetone $\left\{\left(\mathrm{C}_{15} \mathrm{H}_{16} \mathrm{O}_{2}\right)\right.$ 4-(6methoxynaphthalene-2-yl) butan-2-oneArthaxan \} with molecular weight of 228.291 g/mol; CAS no. 42924-53-8 and 98\% purity was the product of Alfa Aesar, A Johnson Mathey Company, whereas cyclosporine was obtained from Santa Cruz Biotechnology, USA.

Experimental design: The mice were divided into three groups i.e two treatment groups and one control group. One treatment group was given Nabumetone at a $14 \mathrm{mg} / \mathrm{kgb}$.w dose through oral route. The other treatment group was given $28 \mathrm{mg} / \mathrm{kgb}$.w. Nabumetone. Normal saline was given as placebo to the control group using a gavage needle. In the treatment groups, Nabumetone was given through the oral route by a gavage needle.

Haemagglutination assay: Mice of the same weight and age were purchased and divided into 3 equal groups. Group 1 was kept as control and not given any drugs except normal saline, whereas group 2 and group 3 were given Nabumetone through the oral route at $14 \mathrm{mg} / \mathrm{kg}$ b.w. and $28 \mathrm{mg} / \mathrm{kg}$ b.w., respectively. Mice in all groups were injected with sheep red blood cells intraperitoneally at $0.5 \times 10^{8}$ on the $14^{\text {th }}$ and $21^{\text {st }}$ days of trial. Blood samples were collected from all three groups, and serum was separated. Antibody titers against sheep red blood cells 
were determined through a hemagglutination inhibition test. The samples were centrifuged at $1000 \mathrm{RPM}$ at $4^{\circ} \mathrm{C}$ for $5 \mathrm{~min}$. The samples were frozen and tested for hemagglutination according to a method described previously (Hassan et al., 2004). The results for treatment groups were compared with those for the control group.

This assay was performed to determine the antibodies titers against sheep red blood cells (SRBCs) according to the method described previously (Jerne et al., 1974). Group 1 was kept as control and given normal saline orally, while group 2 and group 3 were administered Nabumetone at dose $14 \mathrm{mg} / \mathrm{kg}$. b.w. and $28 \mathrm{mg} / \mathrm{kg}$ b.w., respectively, daily for 7 days. Moreover, on the $2^{\text {nd }}$ day all groups were exposed to $5 \%$ of washed SRBCs at dose $0.2 \mathrm{uL}$. On the $6^{\text {th }}$ day, mice were sacrificed by injecting ketamine hydrochloride (10mg/kg.b.w.) intraperitoneally. Spleen was collected, crushed and strained to form a homogenous suspension of single cells in 10 milliliters chilled RPMI-1640 medium to inhibit premature release of antibodies from the cells. The number of splenic cells defined was $1 \times 10^{6} / \mathrm{ml}$ of RPMI. This triturate was sieved and $500 \mu 1$ of filtrate was mixed with equal volume of $2 \%$ SRBCs and $0.7 \%$ warm agarose (Sigma Co, USA) in $200 \mu \mathrm{l}$ RPMI. This mixture was dispensed on glass slides to form a uniform layer and incubated at $37^{\circ} \mathrm{C}$ for two hrs. After incubation, $10 \%$ guinea pig complement in sterilized normal saline was added and incubated overnight at $37^{\circ} \mathrm{C}$ for lysis of SRBCs. The plaques were enumerated and recorded as the number of plaque forming cells per million cells as described in an earlier study (Klebanoff et al., 2005).

Brain heart infusion was used as a growth medium for Pasteurella multocida stored for 24 hsr at $37^{\circ} \mathrm{C}$. The bacteria were suspended in $0.5 \%$ formalin solution. For the preparation of hemorrhagic septicemia vaccine, we used lanoline, bacterial suspension and mineral oil (5:45:50) (Muneer et al., 2005). Mice were treated with Nabumetone at $14 \mathrm{mg} / \mathrm{kg}$ b.w. and $28 \mathrm{mg} / \mathrm{kg}$ b.w. doses for 21 consecutive days, whereas, negative control group was kept as control and injected with normal saline. To ensure the viability of the vaccine, one group was kept as vaccinated control. The animals were injected with hemorrhagic septicemia vaccine on $7^{\text {th }}$ and $17^{\text {th }}$ day of the experiment. Whereas the positive control group was administered cyclosporine at a $100 \mu \mathrm{g} / \mathrm{kg}$ b.w dose through an oral catheter. On the $21^{\text {st }}$ day, all mice were challenged with Pasteurella multocida culture containing $10^{7}$ cells per $\mathrm{ml}(0.2 \mathrm{ml})$. The animals were kept under observation for $72 \mathrm{hrs}$ for determination of mortality in all treated groups.

The data were analyzed with the help of statistical tool one-way analysis of variance (ANOVA) and comparison test i.e LSD (least significant difference) to elaborate the statistical difference between different groups. Statistical package of social sciences (SPSS) is used for more precise description of results. The $\mathrm{P}$ value was at $\mathrm{P}<0.05$.

\section{RESULTS}

There was a decrease $(\mathrm{P}<0.01)$ in serum anti sheep red blood cells titer in the Nabumetone (14mg/kg.b.w.) treated group. Whereas, significant decrease $(\mathrm{P}<0.001)$ in hemagglutination titer was observed in the group treated with a $28 \mathrm{mg} / \mathrm{kg}$.b.w. dose when compared to the control group. So, the titer was lowest in group treated with Nabumetone @ $28 \mathrm{mg} / \mathrm{kg}$.b.w when compared to the group treated with a $14 \mathrm{mg} / \mathrm{kg}$. b.w. dose (Figure 1).

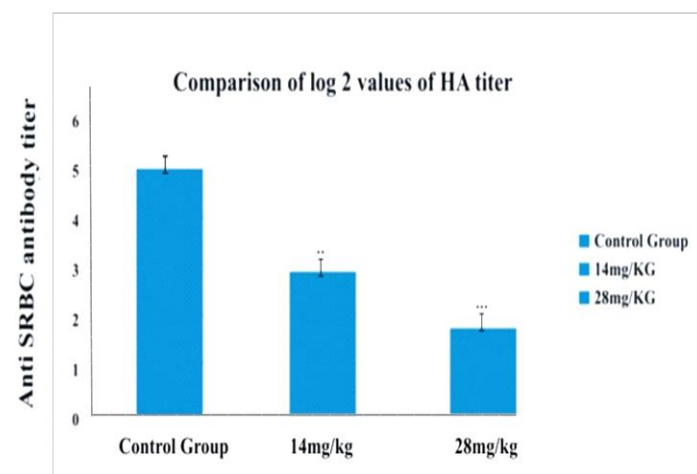

Figure 1. Anit SRBC antibody titer at different doses $(14 \mathrm{mg} / \mathrm{kg}, 28 \mathrm{mg} / \mathrm{kg})$ of Nabumetone.n=5, $* * \mathrm{P}<0.01, * * * \mathrm{P}<0.001 \mathrm{a}$

There was a decrease trend in the production of plasma cells in Nabumetone treated mice. The antigen antibody reaction resulted in plaque formation. Nabumetone resulted in reduced plasma cell formation which ultimately lead to low production of antibodies. Whereas, high plaque formation was observed in the control group (Figure 2). 


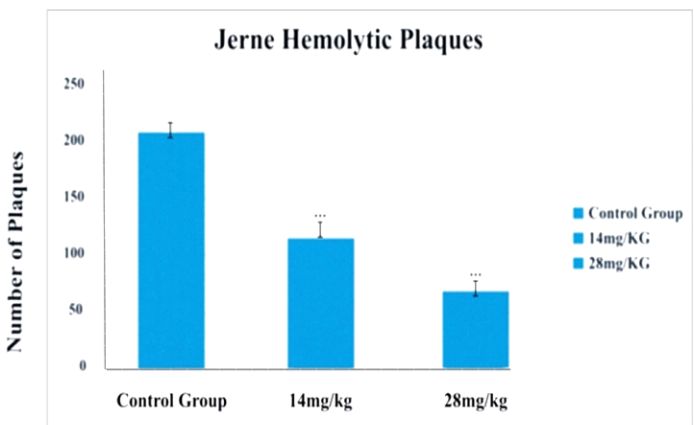

Figure 2. Jerne hemolytic plaque formation when treated with Nebumetone @ $14 \mathrm{mg} / \mathrm{kg}$ b.w. and $28 \mathrm{mg} / \mathrm{kg}$ b.w. in mice

Mortality was observed in Nabumetone and cyclosporine treated groups. In non-vaccinated groups, all mice died within $24 \mathrm{hr}$ after treatment which suggested the viability of vaccine. No mortality was observed in the vaccinated group without Nabumetone. Further, immunity was not suppressed in the vaccinated negative control Nabumetone treated groups. Whereas, 100\% mortality was observed in the positive control group, while $50 \%$ mortality was observed in the Nabumetone treated group at a $14 \mathrm{mg} / \mathrm{kg}$ b.w. dose in mice. However, $100 \%$ mortality was observed in the Nabumetone treated group at a $28 \mathrm{mg} / \mathrm{kg}$ b.w. dose. Cyclosporine was injected in mice at a $100 \mu \mathrm{g} / \mathrm{kg}$ b.w. dose in the positive control group. Mortality rate was higher with a high dose of Nabumetone (Table 1).

Table 1. Percentage mortality in control and Nabumetone treated groups @ $14 \mathrm{mg} / \mathrm{kg}$ b.w. and $28 \mathrm{mg} / \mathrm{kg}$ b.w.

\begin{tabular}{llllll}
\hline Mortality & \multicolumn{3}{l}{ Nabumetone not given } & Nabumetone given & \\
\cline { 2 - 6 } & $\begin{array}{l}\text { Vaccination } \\
+ \text { N.salin }\end{array}$ & $\begin{array}{l}\text { No vaccine } \\
+ \text { N.Saline }\end{array}$ & $14 \mathrm{mg} / \mathrm{kg}$ & $\begin{array}{l}\text { 28mg/kg } \\
\text { Cyclosporine } \\
\text { given }\end{array}$ \\
\cline { 2 - 6 } & $\mathrm{n}=6$ & $\mathrm{n}=6$ & $\mathrm{n}=6$ & $\mathrm{n}=6$ & $\mathrm{n}=6$ \\
\hline Deaths after 24h & 0 & 6 & 2 & 5 & 6 \\
Deaths after 48h & 0 & 0 & 1 & 1 & 0 \\
Deaths after 72h & 0 & 0 & 0 & 0 & 0 \\
Percent deaths & 0 & $100 \%$ & $50 \%$ & $100 \%$ & $100 \%$ \\
\hline
\end{tabular}

\section{DISCUSSION}

Active metabolite of Nabumetone i-e 6MNA inhibits prostaglandin synthesis via inhibition of COX-2 enzyme (Matsumoto et al., 2011). Prostaglandins increase arterial dilatation, microvascular permeability and stimulate messengers that are involved in all aspects of innate and adoptive immune responses including inflammation (Ricciotti and FitzGerald, 2011). Immune responses may result in autoimmune disorders. Immunomodulatory drugs are required in autoimmune diseases.

In present study Nabumetone was given once daily as a single dose in mice. Its active metabolite reached all body parts in mice. Moreover, it was administered orally in mice. Plasma half-life of metabolite of Nabumetone is 24 hours. It is taken once daily as a single dose. Its active metabolite reaches all body parts after $1 / 2$ hour of its administration. As it is a prodrug it must be taken orally (Nobilis et al., 2013).
Humoral immunity is vital for protection of the body against bacterial infections. Lungs respond against bacterial infection as B-cells lead to the production of immunity. IgG and IgA are produced which treats the systemic or local bacterial infection. B-cells lead to formation of plasma cells which results in secretion of antibodies of same type. B-cells also lead to the production of specified microorganisms (Ettinger et al., 2005). In some recent immunological studies, IgM response was studied against SRBCs (Ettinger et al., 2005; Maseda et al., 2014). In hemagglutination assay SRBCs were used for immunization and hemagglutination.

Hemagglutination titer is used to evaluate the humoral immunity based on antigen antibody interaction. For the ease uptake by the phagocytic cells, antibody turns antigen in a suitable form that can be easily ingested. B-cells lead to the secretion of immunoglobulins which destroy the antigen. Further, B-cells are responsible for cytokines as well as antibody 
production through antibodies secreting cells production, which forms when B-cells interact with antigen and lead to diminish the effect of antigen when it interacts with antibodies (Muneer et al., 2005). In this study, it has been proved that due low production of antibodies, hemagglutination titer was decreased steadily when the Nabumetone was given to mice through oral gavage. This phenomenon was dose dependent as low titer was observed at a $28 \mathrm{mg} / \mathrm{kg}$ b.w. dose. HA titer showed that there was lower formation of immunoglobulin $\mathrm{G}$ or $\mathrm{M}$ in all Nabumetone treated groups when exposed to SRBCs.

Spleen plays its vital role in humoral as well as cellular immunity by the stimulation of antibodies producing cells which ultimately lead to the production of antibodies. Lymphocytes and plasma cells are mainly responsible for the production of immunity. Antigen antibody complement is formed in guinea pig. When antibody is formed, it leads to the formation of plaque, however, those cells which produce the antibodies can be seen in the center of the plaque. It is due to the IgM antibody which has ability to attach with complement (Kruetzmann et al., 2003). In our study, dose dependent phenomena were observed where the significant reduction in plaque formation was observed in high dose group (28mg/kg b.w.), while the plaque formation was maximum in the control group that did not receive any drug. This showed low antibody production when the dose of Nabumetone was increased.

Vaccines have been used in order to produce the humoral immunity. Firstly, the body is immunized with vaccine than bacteria are exposed in order to determine the mortality ratio. Vaccination leads to the production of antibodies. Mice have the ability to produce antibodies by the exposure of vaccine and there are more chances of survival when they are exposed to pathogenic bacteria, but it depends upon the production of sufficient antibodies. Pasturella Maltocida is a pathogenic organism which mostly spread through airways (Klebanoff et al., 2005). In this study, mice were first exposed with hemorrhagic septicemia vaccine then to bacteria. Consequently, there was $50 \%$ mortality in mice exposed to Nabumetone at dose $14 \mathrm{mg} / \mathrm{kg}$ b.w., while $100 \%$ mortality was observed in mice exposed to a higher dose (28mg/kg b.w.). Control group showed no mortality. So, Nabumetone worked as an immunosuppressive agent.

\section{REFERENCES}

BERNARD, M.P.; BANCOS, S.; CHAPMAN, T.J.; RYAN, E.P. et al. Chronic inhibition of cyclooxygenase-2 attenuates antibody responses against vaccinia infection. Vaccine, v.28, p.13631372, 2010.

ETTINGER, R.; SIMS, G.P.; FAIRHURST, A.M.; ROBBINS, R. et al. IL-21 induces differentiation of human naive and memory $\mathrm{B}$ cells into antibody-secreting plasma cells. $J$. Immunol., v.175, p.7867-7879, 2005.

FULZELE, S.; SATTURWAR, P.; JOSHI, S.; DORLE, A. Study of the immunomodulatory activity of Haridradi ghrita in rats. Indian $J$. Pharmacol., v.35, p.51-54, 2003.

GONZALO-GARIJO, M.; CORDOBÉSDURAN, C.; LAMILLA-YERGA, A.; MORENO-GASTÓN, I. Severe immediate reaction to nabumetone. J. Investig. Allergol. Clin. Immunol., v.17, p.274, 2007.

HASSAN, Z.M.; OSTAD, S.N.; MINAEE, B. et al. Evaluation of immunotoxicity induced by propoxure in $\mathrm{C} 57 \mathrm{~B} 1 / 6$ mice. Int. Immunopharmacol., v.4, p.1223-1230, 2004.

JERNE, N.K.; HENRY, C.; NORDIN, A.A.; FUJI, H. et al. Plaque forming cells: methodology and theory. Immunol. Rev., v.18, p.130-191, 1974.

KEROLA, M.; VUOLTEENAHO, K.; KOSONEN, O. et al. Effects of nimesulide, acetylsalicylic acid, ibuprofen and nabumetone on cyclooxygenase-1-and cyclooxygenase-2-mediated prostanoid production in healthy volunteers ex vivo. Basic Clin. Pharmacol. Toxicol., v.104, p.17-21, 2009.

KLEBANOFF, C.A.; GATTINONI, L.; TORABI-PARIZI, P.; KERSTANN, K. et al. Central memory self/tumor-reactive CD8+ T cells confer superior antitumor immunity compared with effector memory T cells. Proc. Nat. Acad. Sci., v.102, p.9571-9576, 2005. 
KOENIG， S.; WILDER, R.; BONVINI, E.; JOHNSON, L.S. Methods for the treatment of autoimmune disorders using immunosuppressive monoclonal antibodies with reduced toxicity. Assignee: MacroGenics, Inc., Rockville. US 8,663,634B2. . Filing: 11 July 2006. Date of patent: 4 Mar. 2014.

KRUETZMANN, S.; ROSADO, M.M.; WE, H.; GERMING, U. et al. Human immunoglobulin M memory B cells controlling Streptococcus pneumoniae infections are generated in the spleen. J. Exp. Med., 197, 939-945, 2003.

MASEDA, D.; BONAMI, R.H.; CROFFORD, L.J. Regulation of B lymphocytes and plasma cells by innate immune mechanisms and stromal cells in rheumatoid arthritis. Exp. Rev. Clin. Immunol., v.10, p.747-762, 2014.

MATSUMOTO, K.; NEMOTO, E.; HASEGAWA, T.; AKIMOTO, M.; SUGIBAYASHI, K. In vitro characterization of the cytochrome P450 isoforms involved in the metabolism of 6methoxy-2-napthylacetic acid, an active metabolite of the prodrug nabumetone. Biol. Pharm. Bull., v.34, p.734-739, 2011.
MUNEER, R.; HUSSAIN, M.; ZAHOOR, A. Efficacy of oil based haemorrhagic septicaemia vaccine: a field trial. Int. J. Agric. Biol., v.7, p.571-573, 2005.

NOBILIS, M.; MIKUŠEK, J.; SZOTÁKOVÁ, B.; JIRÁSKO, R. et al. Analytical power of LLE-HPLC-PDA-MS/MS in drug metabolism studies: Identification of new nabumetone metabolites. J. Pharm. Biomed. Anal., v.80, p.164-172, 2013.

RICCIOTTI, E.; FITZGERALD, G.A. Prostaglandins and inflammation. Arterioscler. Thromb. Vasc. Biol., 31, 986-1000, 2011.

SHAPIRO-SHELEF, M.; CALAME, K. Regulation of plasma-cell development. Nat. Rev. Immunol., v.5, p.230, 2005. 